what we had mastered. We do everything possible so that our knowledge speedily becomes the domain of engineers, physicians and agronomists who can give it practical application; the domain of the workers who effect those physical and chemical processes which we investigate. Finally, it is necessary that this knowledge forms part of the foundation of general education in the schools and among the general population.

We organize joint work between scientific men and engineers. Even without planning, science brings benefit, but its role vastly increases when this aim is consciously striven for.

Allow me to disperse some regrettable misunderstandings. The introduction of planned principles in science by no means signifies rejection of fundamental theoretical researches which give no immediate practical results. On the contrary, a proper plan demands that, side by side with the utilization of science for current tasks, it also lays the foundation for the future. History teaches, and our experience proves outright, that major practical results are achieved when succeeding in revealing the mechanism of natural phenomena, when attaining the broadest possible generalizations.

Theory and practice mutually support each other. There is no better checking of theory and analyses of its shortcomings than the experience of mass production. Allow me to cite an instance of my own experience : solely by means of developing quantum theory semi-conductors we have succeeded in raising dozens of times over the current given by new rectifiers, photo-elements and thermo-elements. On the other hand, many features of this theory were prompted by failures in factory production.

Another misunderstanding which has not yet been fully dispersed is the conviction that the sole aim for scientific creation should be the striving for knowledge and not its benefit for mankind. When you learn that so and so many ships with thousands of sailors have been saved, that so and so many airraids threatening our native towns have been averted, that so and so many tanks have been saved owing to your work; if you are given grounds to think that the scientific activity of yourself and your comrades in the Academy of Sciences helps to avert the menace threatening to enslave your people-does not this multiply our strength and promote the success of our research ?

We scientific men enjoy the privilege of combining two supremely gratifying features; in striving for knowledge we thereby increase the happiness of our people and win its recognition. Both these aspects stimulate the development of science and make the man of science a worthy citizen.

Modern science is proceeding by the united efforts of many scientific men who all tackle one problem from various angles. Individual attempts seldom yield important results. Therefore, a man of learning who is isolated from life is not only a bad citizen but also a poor man of science.

I feel that I am not telling you anything new, the reason I am telling you these truisms is that for us they are the result of the experience of twenty-five years on which our science has grown up and which is so highly appreciated by our people. From the first day of war we men of science joined the peoples' ranks and took our stand in the defence of our country. From us scientific men, each soldier and sailor expects help, and we don't disappoint them. As they at the front, we in the laboratory dedicate day and night to our single cause. This is the cause of all scientific men, all citizens who love their freedom and respect the freedom of other nations. Stimulated by patriotic feelings, science constitutes a prepotent force; and this force is in our hands. ...

Before us stretch bright perspectives of progress and free development of all peoples along the roads they themselves may choose. Before us stretch the boundless perspectives of scientific creative endeavour. Let us then unite our efforts quicker to disperse this menace so that the free citizen can breathe deep again. Time does not wait, the sufferings of millions grow.

\title{
OBITUARIES
}

\section{His Eminence Cardinal Hinsley}

Arthur, Cardinal Hinstey, whose death occurred on March 17, was born in 1865 in Yorkshire. He was thus seventy years of age when, on St. George's Day 1935, he took possession of the Metropolitan See of Westminster, to which he had been appointed by Pope Pius XI. In the seven years which followed, he became a great national figure, whose influence extended far beyond the limits of his own flock, and whose clear, uncompromising leadership in his country's crisis was recognized as a great national asset. His voice at the microphone conveyed a message which awakened an immediate response in the heart of the British peoples in every part of the Empire-he could express high thoughts that were struggling for utterance in the nation's soul, in forthright words and manner that the nation recognized as its own.

Such an achievement, in so short a time, and at such an advanced age, was the outcome of immense self-forgetting energy, and should greatly hearten those whose advancing years lead them too easily to give in to feelings of inadequacy. Those who had business with the Cardinal were often amazed at the detailed attention he gave to his correspondence and at the number of letters he wrote with his own hand, at a time when his health was giving constant cause for anxiety. These manuscript letters will long be cherished by those who have them-the writer of this notice has a number of them before him as he writes, each with its words of kindness, of insight and genuine interest, and of encouragement. The Cardinal's personality seems to 'come through' in his letters just as it did in his voice heard on the radio.

Even before his appointment to the See of Westminster, His Eminence had earned a title to the gratitude of his countrymen for the work he had done in the field of education. After graduating at the University of London, he obtained a doctorate at the Gregorian University in Rome and gained the diploma in philosophy of the Academy of St. Thomas. Thereafter his practical interest in education never flagged during the whole of his long life. In 1928 he was appointed Apostolic Visitor to the African Missions in British Territory, and for six arduous years carried out the delicate and responsible task of 
securing the co-operation of missionary educational agencies with the advances in native education being urged at that time by the Colonial Office. His success in this work, and the satisfaction he gave both to ecclesiastical and government circles, were such that in 1930 he was appointed Apostolic Delegate in Africa and his powers consequently extended to missions in certain non-British territories.

During his years at Westminster, the Cardinal maintained the liveliest interest in questions affecting African education, and was instrumental in inaugurating a special colonial course for intending missionaries to fit them for the educational and administrative responsibilities they would be called upon to assume. The main part of this course was given in the Institute of Education of the University of London, and it was supplemented by series of special lectures on cultural anthropology, comparative religion, native psychology, etc.

The Cardinal gave every encouragement to professional men and women of his own flock to play their part fully in the scientific life of the countryespecially in furthering the applications of the social sciences to the material, mental and spiritual wellbeing of mankind. He was quick to recognize good wherever he saw it, and favoured the closest possible co-operation, consistent with firm principles, with the various agencies working in the social field outside his own communion.

WE regret to announce the following deaths :

Major Leonard Darwin, president during 1911-28 of the Eugenics Society, on March 26, aged ninetythree.

Mr. E. Harrison, registrary of the University of Cambridge, and fellow and formerly senior tutor of Trinity College, on March 28, aged sixty-five.

Mr. E. Heron-Allen, F.R.S., known for his work on the Foraminifera, on March 28, aged eighty-one.

Mr. A. Holm, C.M.G., C.B.E., formerly director of agriculture, Kenya, aged sixty-four.

Mr. R. W. Paul, founder of the well-known instrument-making company known by his name, which was eventually amalgamated with the Cambridge Instrument Co., Ltd., on March 28, aged seventythree.

Prof. C. F. Tolman, professor emeritus of economic geology of Stanford University, on October 13, aged sixty-nine years.

Mr. W. Trevor Watson, K.C., who specialized in patent law and scientific cases, on March 24, aged fifty-six.

\section{NEWS and VIEWS}

\section{Avebury}

But for the War, the acquisition by the National Trust of Avebury, and also of Windmill Hill, would certainly have created a more considerable stir. This Bronze Age monument is one of the most impressive of its kind in Europe ; and the lesser site at Windmill Hill has given its name to one of the main neolithic pottery groups of the British Isles. Doubtless the Avebury stone circle owed its importance to its geographical position, situated as it was at the meeting place of a number of ancient downland roads. In its prime, after its last reconstruction, it must have formed a magnificent ensemble with its great circular ditch and rampart and approaching avenue of tall standing stones. Great Britain owes a great deal to Mr. Keiller, who has been excavating Avebury at his own expense for many years past. The lack of interest in former days, and the propinquity of a village, had resulted in the partial destruction of a great deal of the monument and the breaking up of many of the stones for building purposes. Mr. Keiller acquired the property and set to work to examine the site scientifically, and, where possible, to re-erect the fallen stones. The result has been the saving of a unique possession. Windmill Hill, too, is of extreme scientific interest. Earlier in date than the Avebury we see to-day, its excavation has yielded precious data for the elucidation of British culture at a remote period. It is satisfactory to feel that the monuments and Mr. Keiller's work on them will now be preserved for all time for the nation.

\section{Engineering Economics}

THrs was the title of a paper presented on March 25 before a joint meeting of the Institutions of Civil, Mechanical and Electrical Engineers by Sir Frank Gill, who explained that his purpose was to urge the leading institutions to include the subject of engineer- ing economics in the qualifications required for admission to corporate membership. Although an essential part of the equipment of a practising engineer in fitting him to decide or advise upon the most economically sound detail or scheme to adopt, this is a branch of training which has, in the main, received little attention. He described 'engineering economics'-distinct from the university meaning of economics-as being related to the question "Which of several plans, schemes or designs, each technically sound for the same job, is it advantageous to select?" Engineering plans and decisions must be technically sound ; they must also be financially advantageous, and to stress this view several examples were mentioned. In deciding upon the size of a telephone exchange, for example, the advantages increase up to a certain number of subscribers but beyond this they diminish, and it was for a training in the methods by which such economic analyses should be made that Sir Frank pleaded.

Unfortunately, the discussion was mainly wide of the mark, and most of the speakers criticized mere details such as the limited nature of the examples cited, which had no real bearing on the point at issue. Although not helpful, the remarks made by the several speakers carried the implication that the training advocated by Sir Frank is necessary. How advantageous, then, would have been a discussion on the method by which the training might be given, at what stage and the means by which the obvious difficulties might be overcome in the schools. Prof. R. O. Kapp, Pender professor of electrical engineering at University College, London, alone gave some suggestions from his experience in trying to fill the gap, and one came away feeling that, with good will, teachers in the universities and colleges could very easily give a lead in inculcating the principles and technique by introducing an economic as well as a technical objective in the problems and designs which are set for the training of their students. 